\title{
Vitellibacter aestuarii sp. nov., isolated from tidal- flat sediment, and an emended description of the genus Vitellibacter
}

Correspondence

Jongsik Chun

jchun@snu.ac.kr

\author{
Bong-Soo Kim,† Ok-Sun Kim, Eun Young Moon and Jongsik Chun
}

\author{
School of Biological Sciences and Institute of Microbiology, Seoul National University, \\ Seoul 151-742, Republic of Korea
}

\begin{abstract}
A Gram-reaction-negative, aerobic, yellowish-orange-pigmented bacterial strain, designated $\mathrm{JC} 436^{\top}$, was isolated from tidal-flat sediment of Oi Island in Korea. Comparative 16S rRNA gene sequence analysis indicated its close affiliation to Vitellibacter vladivostokensis, with $96 \%$ sequence similarity to the type strain. Cells grew with $2-6 \% \mathrm{NaCl}$ and at $10-41{ }^{\circ} \mathrm{C}$. Orange flexirubin pigments were present. The major isoprenoid quinone was MK-6, the DNA G + C content was $48.7 \mathrm{~mol} \%$ and the predominant fatty acids $(>10 \%)$ were iso- $\mathrm{C}_{15: 0}$ and iso- $\mathrm{C}_{17: 0}$ $3-\mathrm{OH}$. The data obtained from this polyphasic study support the classification of this isolate within a novel species in the genus Vitellibacter, for which the name Vitellibacter aestuarii sp. nov. is proposed. The type strain is $\mathrm{JC} 2436^{\top}\left(=\mathrm{MMSNU} 14137^{\top}=\mathrm{KACC} 13727^{\top}=\mathrm{KCTC} 22361^{\top}\right.$ $=\mathrm{JCM} 15496^{\mathrm{T}}$ ).
\end{abstract}

Members of the phylum Bacteroidetes (formerly the Cytophaga-Flavobacterium-Bacteroides group) are widespread and represent a large proportion of the microbial communities in marine environments. Some of these bacteria play important roles in the degradation of dissolved and particulate organic matter in nature (Cottrell \& Kirchman, 2000; Devey et al., 2001). Tidal-flat sediments represent a marine environment that has been recognized as an important place for bioremediation; they have recently yielded various novel bacterial taxa (Kim et al., 2004; Yi \& Chun, 2006), including many members of the family Flavobacteriaceae in the phylum Bacteroidetes (Choi et al., 2006; Kim et al., 2008). The genus Vitellibacter and species Vitellibacter vladivostokensis in the family Flavobacteriaceae were described to accommodate a strain isolated from a holothurian in the Sea of Japan (Nedashkovskaya et al., 2003). Here, we present the polyphasic characterization of a bacterial isolate from tidal-flat sediment for which we propose a novel species in the genus Vitellibacter.

Strain $\mathrm{JC}^{2} 436^{\mathrm{T}}$ was isolated from tidal flat sediment of Oi Island in Korea $\left(37^{\circ} 20.533^{\prime} \mathrm{N} 126^{\circ} 41.333^{\prime} \mathrm{E}\right)$ using marine agar 2216 (MA; Difco) at $30^{\circ} \mathrm{C}$. The isolate was preserved as a glycerol suspension $\left(20 \%, \mathrm{w} / \mathrm{v}\right.$, in distilled water) at $-80{ }^{\circ} \mathrm{C}$.

The $16 \mathrm{~S}$ rRNA gene was amplified and sequenced from a single colony as described previously (Chun \& Goodfellow, 1995). Identification of phylogenetic neighbours was

tPresent address: Division of Microbiology, National Center for Toxicological Research/US FDA, Jefferson, AR 72079, USA.

The GenBank/EMBL/DDBJ accession number for the 16S rRNA gene sequence of strain $\mathrm{JC} 436^{\top}$ is EU642844. carried out by using the BLAST program (Altschul et al., 1997) against the database of the EzTaxon server (http:// www.eztaxon.org/; Chun et al., 2007). The 100 sequences with the highest alignment scores were then selected for the calculation of pairwise sequence similarity using a global alignment algorithm implemented at the EzTaxon server. The nearly complete 16S rRNA gene sequence of strain JC2436 $^{\mathrm{T}}$ (1395 bp) was obtained and aligned manually against those of members of the nearest genera of the family Flavobacteriaceae using a bacterial $16 \mathrm{~S}$ rRNA secondary structure model. The regions available for all sequences (positions 96-1412; Escherichia coli numbering system) showed unambiguous alignment and were used to construct phylogenetic trees. Phylogenetic analyses were carried out using the jPHYDIT program (Jeon et al., 2005; http://chunlab.snu.ac.kr/jphydit/) and PAUP 4.0 (Swofford, 1998) as described previously (Chun et al., 2000; Yi \& Chun, 2006). Phylogenetic trees were inferred by using the maximum-likelihood (Felsenstein, 1981), maximumparsimony (Fitch, 1971) and neighbour-joining (Saitou \& Nei, 1987) methods. The resultant tree topologies were evaluated by bootstrap analyses (Felsenstein, 1985) based on 1000 resamplings.

Strain JC2436 ${ }^{\mathrm{T}}$ showed the highest 16S rRNA gene sequence similarity to Vitellibacter vladivostokensis KMM $3516^{\mathrm{T}}$ (96\%), followed by the type strains of Aequorivita species (93.2-94\%). The neighbour-joining tree showed that the isolate formed a monophyletic clade with the type strain of $V$. vladivostokensis (Fig. 1) with $88 \%$ bootstrap support. This relationship was also found in the maximumparsimony and maximum-likelihood trees. 


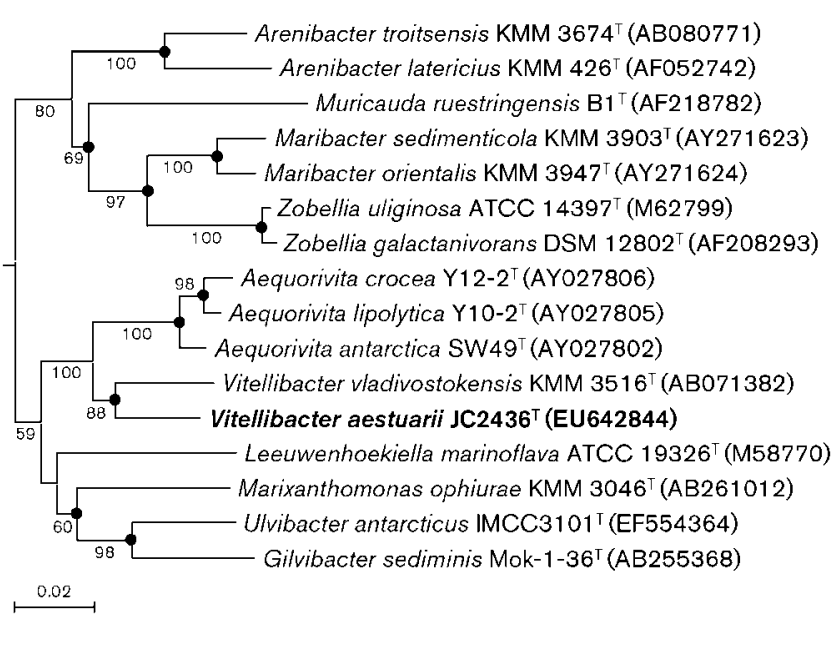

Fig. 1. Neighbour-joining tree based on 16S rRNA gene sequences of strain $\mathrm{JC} 2436^{\top}$ and closely related members of the family Flavobacteriaceae. The sequence of Chryseobacterium balustinum ATCC $33487^{\top}$ was used as the outgroup (GenBank accession no. M58771; not shown). Percentages at nodes are levels of bootstrap support (>50\%) from 1000 resampled datasets. Solid circles indicate that the corresponding nodes (groupings) were also recovered in the maximum-likelihood and maximum-parsimony trees. Bar, 0.02 substitutions per nucleotide position.

Growth at various $\mathrm{NaCl}$ concentrations was investigated in sea-salt-free Zobell's agar (ZoBell, 1941; 15 g Bacto agar, $5 \mathrm{~g}$ Bacto peptone, $1 \mathrm{~g}$ yeast extract, $0.1 \mathrm{~g}$ ferric citrate in $1000 \mathrm{ml}$ distilled water). The temperature range for growth was determined optically in a temperature gradient incubator (model TVS 126MA; Advantec) using marine broth 2216 (MB; Difco) in the range $4-45{ }^{\circ} \mathrm{C}$. Growth under anaerobic conditions was assessed in an anaerobic chamber on MA that had been prepared anaerobically under a nitrogen atmosphere. Gliding motility was determined as described by Bowman (2000). Strain JC2436 ${ }^{\mathrm{T}}$ did not grow under anaerobic conditions. The temperature range for growth was $10-41{ }^{\circ} \mathrm{C}$ (optimum, $30-35{ }^{\circ} \mathrm{C}$ ). Growth occurred with $2-6 \% \mathrm{NaCl}$ (optimum, $2-3 \%$ ).

Comparative phenotypic characterization was carried out in parallel on strain JC2436 ${ }^{\mathrm{T}}$ and the reference strain $V$. vladivostokensis $\mathrm{KMM} 3516^{\mathrm{T}}$. Biochemical tests were performed using the API 20NE and API ZYM kits (bioMérieux) and GN2 MicroPlates (Biolog). A heavy cell suspension in AUX medium (bioMérieux) with $2.5 \% \mathrm{NaCl}$ was dispensed into each well of the API kits. All kits were incubated at $30{ }^{\circ} \mathrm{C}$ for 5 days. The oxidase test was performed using a commercial oxidase reagent (bioMérieux). Catalase activity was tested by addition of a $3 \%(\mathrm{v} / \mathrm{v}) \mathrm{H}_{2} \mathrm{O}_{2}$ solution to colonies. Flexirubin pigments were detected using $20 \%(\mathrm{w} / \mathrm{v})$ $\mathrm{KOH}$, a colour change from yellow or orange to brown-red indicating the presence of pigments (Fautz \& Reichenbach, 1980). Acid production from carbohydrates was examined using API 50 CHB kits (bioMérieux). Hydrolysis of starch
$(0.2 \%, \mathrm{w} / \mathrm{v})$, casein $(50 \%, \mathrm{v} / \mathrm{v}$, skimmed milk), cellulose $(0.5 \%, w / v$, CM-cellulose; Sigma), Tweens 20, 40, 60 and 80 $(1 \%, \mathrm{v} / \mathrm{v})$, chitin $(1 \%, \mathrm{w} / \mathrm{v})$ and elastin $(2 \%, \mathrm{w} / \mathrm{v})$ was detected using MA as the basal medium (Nedashkovskaya et al., 2003; Smibert \& Krieg, 1994). Susceptibility to antibiotics [ampicillin $(10 \mu \mathrm{g})$, benzylpenicillin $(10 \mu \mathrm{g})$, carbenicillin $(100 \mu \mathrm{g})$, gentamicin $(10 \mu \mathrm{g})$, kanamycin $(30 \mu \mathrm{g})$, lincomycin $(15 \mu \mathrm{g})$, neomycin $(30 \mu \mathrm{g})$, oleandomycin $(15 \mu \mathrm{g})$, polymyxin $\mathrm{B}$ (300 U), streptomycin $(10 \mu \mathrm{g})$ and tetracycline $(30 \mu \mathrm{g})$; discs from Adventec] was examined according to Nedashkovskaya et al. (2003) using the disc diffusion method. The results of biochemical and physiological tests are shown in Table 1 and in the species description.

The cellular fatty acid compositions of the test strain and $V$. vladivostokensis KMM $3516^{\mathrm{T}}$ were analysed by GLC according to the instructions of the Microbial Identification System (MIDI) using cells grown on $\mathrm{MA}$ at $30{ }^{\circ} \mathrm{C}$ for 5 days. The same growth conditions had originally been used to grow $V$. vladivostokensis $\mathrm{KMM} 3516^{\mathrm{T}}$, except that the temperature was $28{ }^{\circ} \mathrm{C}$ (Nedashkovskaya et al., 2003). Overall, the fatty acid profiles of the two strains were very similar, with only slight difference in the proportions of some components (Table 2). The DNA G + C content of strain JC2436 ${ }^{\mathrm{T}}$ was determined by HPLC analysis of deoxyribonucleosides as described by Mesbah et al. (1989), using a reversed-phase column (Supelcosil LC-18 S; Supelco). The G+C content of strain JC2436 ${ }^{\mathrm{T}}$ was $48.7 \mathrm{~mol} \%$, while that of $V$. vladivostokensis KMM $3516^{\mathrm{T}}$ was reported as $41.3 \mathrm{~mol} \%$ (Nedashkovskaya et al., 2003). Menaquinones were extracted, purified and analysed by using a modification of the HPLC method (Collins, 1994).

On the basis of 16S rRNA gene sequence similarity and phylogenetic analysis, strain $\mathrm{JC} 436^{\mathrm{T}}$ exhibited a close relationship to $V$. vladivostokensis $\mathrm{KMM} 3516^{\mathrm{T}}$. The two strains shared several important phenotypic characteristics, strongly suggesting that they belong to the same genus, such

Table 1. Characteristics that differentiate strain $\mathrm{JC} 2436^{\top}$ from V. vladivostokensis $\mathrm{KMM} 3516^{\top}$

Strains: 1, JC2436 ${ }^{\mathrm{T}} ; 2$, V. vladivostokensis $\mathrm{KMM} 3516^{\mathrm{T}}$. All data were obtained in this study except the DNA $\mathrm{G}+\mathrm{C}$ content of $V$. vladivostokensis KMM $3516^{\mathrm{T}}$ (from Nedashkovskaya et al., 2003).

\begin{tabular}{|lcc|}
\hline Characteristic & $\mathbf{1}$ & $\mathbf{2}$ \\
\hline Catalase & - & + \\
Growth temperature $\left({ }^{\circ} \mathrm{C}\right)$ & & \\
$\quad$ Optimum & $30-35$ & 28 \\
$\quad$ Range & $10-41$ & $4-43$ \\
NaCl concentration range for growth (\%) & $2-6$ & $1-6$ \\
Susceptibility to: & - & + \\
$\quad$ Ampicillin & + & - \\
$\quad$ Benzylpenicillin & - & + \\
$\quad$ Lincomycin & - & + \\
Hydrolysis of Tween 40 & 48.7 & 41.3 \\
DNA G + C content $(\mathrm{mol} \%)$ & & \\
\hline
\end{tabular}


Table 2. Fatty acid compositions of strain $\mathrm{JC} 2436^{\top}$ and V. vladivostokensis $\mathrm{KMM} 3516^{\top}$

Strains: 1, JC2436 ${ }^{\mathrm{T}}$; 2, V. vladivostokensis $\mathrm{KMM} 3516^{\mathrm{T}}$. Values are percentages of total fatty acids and were obtained in this study. -, Not detected; fatty acids that amounted to $<1 \%$ in both strains are not shown.

\begin{tabular}{|lcr|}
\hline Fatty acid & $\mathbf{1}$ & $\mathbf{2}$ \\
\hline iso- $\mathrm{C}_{15: 1}$ & 3.3 & 2.4 \\
iso- $\mathrm{C}_{15: 0}$ & 37.6 & 32.4 \\
anteiso- $\mathrm{C}_{15: 0}$ & 3.6 & 3.8 \\
$\mathrm{C}_{15: 0}$ & 4.2 & 4.3 \\
iso- $\mathrm{C}_{16: 0}$ & 1.2 & 2.7 \\
Summed feature 3* & 9.3 & 6.9 \\
$\mathrm{C}_{16: 0}$ & 1.6 & 1.7 \\
iso- $_{15: 0} 3-\mathrm{OH}$ & 4.6 & 3.5 \\
iso- $\mathrm{C}_{17: 1} \omega 9 c$ & 5.1 & 9.0 \\
iso- $\mathrm{C}_{17: 0}$ & - & 2.0 \\
iso- $\mathrm{C}_{16: 0} 3-\mathrm{OH}$ & 1.5 & 1.4 \\
iso- $\mathrm{C}_{17: 0} 3-\mathrm{OH}$ & 21.1 & 23.2 \\
\hline
\end{tabular}

${ }^{*}$ Summed features are groups of two or three fatty acids that cannot be separated by GLC with the MIDI system. Summed feature 3 contains iso- $\mathrm{C}_{15: 0} 2-\mathrm{OH}$ and/or $\mathrm{C}_{16: 1} \omega 7 c$.

as the absence of flagella, the inability to produce endospores, the presence of MK-6 as the major quinone and the production of flexirubin pigments, oxidase and alkaline phosphatase. On the other hand, the two strains showed rather low 16S rRNA gene sequence similarity (96\%) and could be differentiated from each other by a number of phenotypic characteristics (Table 1). We therefore propose that strain JC2436 ${ }^{\mathrm{T}}$ be assigned to a novel species in the genus Vitellibacter, for which the name Vitellibacter aestuarii sp. nov. is proposed. We also emend the description of the genus Vitellibacter to accommodate the novel species.

\section{Emended description of the genus Vitellibacter Nedashkovskaya et al. 2003}

Cells are Gram-reaction-negative, strictly aerobic rods that produce non-diffusible yellow-orange flexirubin pigments. Cells do not form endospores, they are not flagellated and gliding motility is not observed. Cells require $\mathrm{Na}^{+}$for growth and are chemo-organotrophic. Cells are oxidase- and alkaline phosphatase-positive. The major respiratory quinone is $\mathrm{MK}$ 6 . The main cellular fatty acids are iso- $\mathrm{C}_{15: 0}$ and iso- $\mathrm{C}_{17: 0} 3-$ $\mathrm{OH}$. The DNA G $+\mathrm{C}$ content is approximately $41-49 \mathrm{~mol} \%$. The type species is Vitellibacter vladivostokensis.

\section{Description of Vitellibacter aestuarii sp. nov.}

Vitellibacter aestuarii (aes.tu.a'ri.i. L. gen. n. aestuarii of a tidal flat).

The description is the same as the emended description of the genus with the following additional characteristics.
Cells are approximately $8 \mu \mathrm{m}$ long. Colonies on MA are circular with regular edges, convex and yellowish orange. Growth occurs with 2-6\% (w/v) $\mathrm{NaCl}$ (optimum, 2-3\%) and at $10-41{ }^{\circ} \mathrm{C}$ (optimum, $30-35{ }^{\circ} \mathrm{C}$ ). Cells are catalasenegative. Decomposes gelatin (API 20NE), casein, elastin, DNA and Tween 20, but not Tweens 40,60 or 80 , chitin, starch or CM-cellulose. Esterase (C4), esterase lipase (C8), leucine arylamidase, valine arylamidase and cystine arylamidase activities are present, as are weak lipase (C14), naphthol-AS-BI-phosphohydrolase and acid phosphatase activities. Trypsin, $\alpha$-chymotrypsin, $\alpha$-galactosidase, $\beta$ galactosidase, $\beta$-glucuronidase, $\alpha$-glucosidase, $\beta$-glucosidase, $\alpha$-mannosidase, $N$-acetyl- $\beta$-glucosaminidase and $\alpha$ fucosidase activities are absent (API ZYM). Acid is not produced from any of the carbohydrates in API $50 \mathrm{CHB}$ kits. Does not reduce nitrate to nitrite. Susceptible to carbenicillin and benzylpenicillin, but not to ampicillin, gentamicin, kanamycin, lincomycin, neomycin, oleandomycin, polymyxin $\mathrm{B}$, streptomycin or tetracycline. The DNA G + C content of the type strain is $48.7 \mathrm{~mol} \%$. The detailed fatty acid composition of the type strain is given in Table 2.

The type strain, JC2436 ${ }^{\mathrm{T}}\left(=\mathrm{IMSNU} 14137^{\mathrm{T}}=\mathrm{KACC}\right.$ $13727^{\mathrm{T}}=$ KCTC $22361^{\mathrm{T}}=$ JCM $\left.15496^{\mathrm{T}}\right)$, was isolated from tidal-flat sediment of Oi Island, Korea.

\section{Acknowledgements}

This work was supported by the Korea Ministry of Science and Technology under the National Research Laboratory Program (R0A2005-000-10110-0) and a grant from the Regional Sub-GeneBank Support Program of the Rural Development Administration, Republic of Korea.

\section{References}

Altschul, S. F., Madden, T. L., Schaffer, A. A., Zhang, J., Zhang, Z., Miller, W. \& Lipman, D. J. (1997). Gapped BLAST and PSI-BLAST: a new generation of protein database search programs. Nucleic Acids Res 25, 3389-3402.

Bowman, J. P. (2000). Description of Cellulophaga algicola sp. nov., isolated from the surfaces of Antarctic algae, and reclassification of Cytophaga uliginosa (Zobell and Upham 1944) Reichenbach 1989 as Cellulophaga uliginosa comb. nov. Int J Syst Evol Microbiol 50, 18611868.

Choi, D. H., Kim, Y. G., Hwang, C. Y., Yi, H., Chun, J. \& Cho, B. C. (2006). Tenacibaculum litoreum sp. nov., isolated from tidal flat sediment. Int J Syst Evol Microbiol 56, 635-640.

Chun, J. \& Goodfellow, M. (1995). A phylogenetic analysis of the genus Nocardia with $16 \mathrm{~S}$ rRNA gene sequences. Int J Syst Bacteriol 45, 240-245.

Chun, J., Bae, K. S., Moon, E. Y., Jung, S. O., Lee, H. K. \& Kim, S. J. (2000). Nocardiopsis kunsanensis sp. nov., a moderately halophilic actinomycete isolated from a saltern. Int J Syst Evol Microbiol 50, 1909-1913.

Chun, J., Lee, J. H., Jung, Y., Kim, M., Kim, S., Kim, B. K. \& Lim, Y. W. (2007). EzTaxon: a web-based tool for the identification of prokaryotes based on 16S ribosomal RNA gene sequences. Int J Syst Evol Microbiol 57, 2259-2261. 
Collins, M. D. (1994). Isoprenoid quinones. In Chemical Methods in Prokaryotic Systematics, pp. 265-309. Edited by M. Goodfellow \& A. G. O'Donnell. Chichester: Wiley.

Cottrell, M. T. \& Kirchman, D. L. (2000). Natural assemblages of marine proteobacteria and members of the Cytophaga-Flavobacter cluster consuming low- and high-molecular-weight dissolved organic matter. Appl Environ Microbiol 66, 1692-1697.

Devey, K. E., Kirby, R. R., Turley, C. M., Weightman, A. J. \& Fry, J. C. (2001). Depth variation of bacterial extracellular enzyme activity and population diversity in the northeastern North Atlantic Ocean. Deep Sea Res Part 2 Top Stud Oceanogr 48, 1003-1017.

Fautz, E. \& Reichenbach, H. (1980). A simple test for flexirubin-type pigments. FEMS Microbiol Lett 8, 87-91.

Felsenstein, J. (1981). Evolutionary trees from DNA sequences: a maximum likelihood approach. J Mol Evol 17, 368-376.

Felsenstein, J. (1985). Confidence limits on phylogenies: an approach using the bootstrap. Evolution 39, 783-791.

Fitch, W. M. (1971). Toward defining the course of evolution: minimum change for a specific tree topology. Syst Zool 20, 406-416.

Jeon, Y. S., Chung, H., Park, S., Hur, I., Lee, J. H. \& Chun, J. (2005). jPHYDIT: a JAVA-based integrated environment for molecular phylogeny of ribosomal RNA sequences. Bioinformatics 21, 3171-3173.

Kim, B. S., Oh, H.-M., Kang, H., Pack, S.-S. \& Chun, J. (2004). Remarkable bacterial diversity in the tidal flat sediment as revealed by $16 \mathrm{~S}$ rDNA analysis. J Microbiol Biotechnol 14, 205-211.
Kim, J. H., Kim, K. Y., Hahm, Y. T., Kim, B. S., Chun, J. \& Cha, C. J. (2008). Actibacter sediminis gen. nov., sp. nov., a marine bacterium of the family Flavobacteriaceae isolated from tidal flat sediment. Int J Syst Evol Microbiol 58, 139-143.

Mesbah, M., Premachandran, U. \& Whitman, W. B. (1989). Precise measurement of the $\mathrm{G}+\mathrm{C}$ content of deoxyribonucleic acid by highperformance liquid chromatography. Int J Syst Bacteriol 39, 159167.

Nedashkovskaya, O. I., Suzuki, M., Vysotskii, M. V. \& Mikhailov, V. V. (2003). Vitellibacter vladivostokensis gen. nov., sp. nov., a new member of the phylum Cytophaga-Flavobacterium-Bacteroides. Int J Syst Evol Microbiol 53, 1281-1286.

Saitou, N. \& Nei, M. (1987). The neighbor-joining method: a new method for reconstructing phylogenetic trees. Mol Biol Evol 4, 406425.

Smibert, R. M. \& Krieg, N. R. (1994). Phenotypic characterization. In Methods for General and Molecular Bacteriology, pp. 607-654. Edited by P. Gerhardt, R. G. E. Murray, W. A. Wood \& N. R. Krieg. Washington, DC: American Society for Microbiology.

Swofford, D. L. (1998). Phylogenetic analysis using parsimony (PAUP), version 4. Sunderland, MA: Sinauer Associates.

Yi, H. \& Chun, J. (2006). Thalassobius aestuarii sp. nov., isolated from tidal flat sediment. J Microbiol 44, 171-176.

ZoBell, C. E. (1941). Studies on marine bacteria. I. The cultural requirements of heterotrophic aerobes. J Mar Res 4, 42-75. 